DOI: 10.19085/journal.sijbpg030901

\title{
An Exploration Of The Challenges Of Micro, Small And Medium Scale Farmers In Ile-Ife Township Of Osun State, Nigeria
}

\author{
Ajayi, Adeola \\ Department of Public Administration, ObafemiAwolowo University Ile-lfe, Osun State, Nigeria.
}

(c) Scholedge International Journal of Business Policy \& Governance (ISSN 2394-3351), Vol.03, Issue 09 (2016) pg122-134.

Published by: Scholedge R\&D Center [http://www.thescholedge.org/journals/] [Email: editorial@thescholedge.org]

\begin{abstract}
This study explored the factors suppressing micro, small and medium enterprising (MSME) farmersin Ile-Ife Township of Osun State, Nigeria with a view to find the obstaclesmilitating against the performance of the small and medium enterprises subsector to the Nigeria economy and recommend ameliorative measures to make the sub-sector strong and vibrant in order to play the crucial role in Nigeria economy growth and development.Primary and secondary sources of data were utilized for the study. Primary sources of data were employed using structures questionnaires while secondary sources were from books, journals, newspapers, internet sources and public lectures on the field of industrial small and medium scale farmers. Multi stage random sampling was used to select a total of 120 respondents utilized for the study. Both descriptive and inferential statistics were used to achieve the objectives of the study. The results from the questionnaires revealed that SMEs have performed below expectation due to a combination of challenges which ranges from financial constraint, poor managerial skills, poor road network, weakness in organizational marketing and information, low and dwindling consumer personal, multiple taxes, insecurity of lives and properties and lexies, attitude and habits of SME famers themselves through frequent policy changes and somersault government instability and environmental related factor among others. The paper concluded that government should take a practical radical approach to address the identified problems of SME farmers inlle-Ife Township of Osun State, Nigeria.
\end{abstract}

Kewwords: Development,Employment Generation, Income Generation, Poverty Reduction Small and Medium Farmers 


\section{INTRODUCTION}

Small and MediumEnterprising farmers have drawn a lot of interest among scholars, policy makers, business meant and people in general.

SME farmers are one of the principal forces in the development of a nation. The SME farmers stimulate private ownership and entrepreneurial skills and can adapt quickly to changing market situation, generate employment help diversify economic activities and make a significant contribution to exports and trade. International agencies and organizations (World Bank, United Nations Industrial Development Organization (UNIDO), Department for International Agencies and Organizations (World Bank, United Nations Industrial Development Organization (UNIDO), Department for International Development (DFID) Europe an investment Bank (EIB) have invested in them. Locally, several non-governmental organizations such as Fate Foundation, Support and Training Entrepreneurship Programme (STEP) the Nigeria Investment PromotionCommission (NIPC) have been promoting the growth of SMEs in Nigeria through advocacy and capacity building initiatives and have continued to canvass for better support structures for operators in the SME subsector(Onugu,2005).

Small and Medium Enterprising farmers occupy a place of pride in virtually every country of the world. Because of their (SME farmers) significant roles in the growth and development of various economics, they have been aptly referred to as "the engine catalysts for socio-economic transformation of any country" (Ajagu, 2005).

They also represent a veritable vehicle for the achievement of national economic objectives of employment generation and poverty reduction at low investment cost as well as the development entrepreneurial capabilities including indigenous technology (Fatai,2011).

It has however been worrisome that despite the incentives, policies, programmes and support aimed at revamping the SME farmers, they have reformed below expectationin Nigeria.Thus this study sets out to explore the factors suppressing SME farmers in Ile-Ife Township of Osun State, Nigeria.

\section{Statement of the Problem}


Small and Medium Enterprises (SME farmers) in Nigeria has fallen short of expectation and hence have not played the vital role to the economy growth of Nigeria. This situation has been of great concern to this government, citizenry, operators, practitioners and the organized private sector groups. This situation is more disturbing and worrisome when compared with the SME farmers in developed countries. It has been shown that there is a high correlation between the degrees of poverty hunger, unemployment, economic well-being (standard of living) of the citizens or countries and the degree or vibrancy of the respective country's SME farmers.

The time is now to do something surgical to this situation of our SME farmers given the aggravating level of poverty in Nigeria and the need to meet up with time. It is against these background problems that the researcher investigates the challenges of small and medium scale enterprising farmers in Ile-Ife Township of Osun State, Nigeria and recommends solutions to reduce these challenges.

\section{Objective of the Study}

The objectives of the study are to:review literature on Small and Medium Scale Enterprising Farmers, identify challenges of Small and Medium Scale Enterprising Farmers; andmake appropriate recommendations for solving or alleviating the identified challenges of the Small and Medium Scale Enterprising Farmers inlle-Ife Township of Osun State,Nigeria.

\section{LITERATURE REVIEW}

Many scholars have written about Small and MediumEnterprising Farmersin Nigeria. This fact underscores the essence, importance and relevance of SME farmers to the development of any given economy.

It has drawn a lot of interest among scholars, policy makers, businessmen and people in general. The role played by SMEs in developed economics buttresses the fact that SME Farmers is an engine of growth and development of many nations (Chowdhury, 2007). 
This stems from the fact almost all countries that focused on the SME Farmers have succeeded in the significant reduction and its enhancement in the quality and standard of living, reduction in crime rate, increase in per capital income as well as rapid growth in EDP among other salutary effects(Mordi, 2005).

National Council on Industry (1992) defined Small Scale Enterprises as those with fixed assets above 1million naira but not exceeding 10million naira excluding land but including working capital while Medium Scale Enterprising Farmers are those with fixed assets, excluding land but including working capital of over 10 million naira but not exceeding 4omillion naira.

This definition was revised in 1996 with Small Scale Enterprises defined as enterprises with total cost above 1 million naira but not exceeding 4omillion naira, with a labour size of between 11 and 35 workers while Medium Scale Enterprises area defined as enterprises with total cost above 15omillion naira and a labour size over 100 workers.

Gbolami (2006) et al. (2010) regarded SMEs as firms that have fewer employees and a lower turnover and assets than large firms such as multi-national companies.

According to Onugu (ibid), SMEs are increasingly recognized as the principal means for achieving equitable and sustainable industrial diversification and dispersal .In most counties of the world, SMEs account for well over half of the total share of employment, sales and value added.

European Union also defined SMEs as enterprises which employ fewer than 250persons and which have an annual turnover not exceeding 50million euro or an annual balance sheet total not exceeding 43million euro.

Gholami et al. (2010) regarded SMEs as firms that have fewer employees and a lower annual turnover and assets than large firms such as multi-national companies. Hudson et al. (2001) also agreed that SMEs may be differentiated from larger companies a number of key characteristics such as personalized management with devolution of authority, resource limitations in in terms of management and manpower, finance, reliance on a number of small customers, limited market 
operations, flat and flexible structures, high innovatory potential, reactive fire-fighting mentality and informal dynamic strategies.

There is a consensus that if all stakeholders are to show serious commitment to the development of the SMEs sub-sector it follows that the economy must witness meaningful transformation and prosperity. SMEs help to provide opportunity for employment generation and effective means of curtailing rural-urban migration and resource utilization. By largely producing intermediate products for use in large-scale companies, SMEs contribute to the strengthening of industrial inter-linkages and integration (Ahmed, 2009).

Many international development agencies, organizations and financiers not only appreciate the roles played by SMEs in poverty alleviation and overall economic growth and development, but also invest significant percentages of their resources in them (SMEs).

A review of World Bank Operations revealed that it invested a whopping 100 billion dollars in SMEs in 2013 with Africa getting a sizeable share or 50 million dollars (CBN,2014). This sum was channelled through time four major development arms of the bank: International Finance Corporation (IFC), the Multilateral Investment Guarantee Agency (MIEA). This International Bank for Reconstruction and Development (IBRD) and the International Development Association (IDA). Nigeria benefitted from part of the project development to the tune of 220 billion naira in 2014 (Field Work, 2014).

The SMEs have no doubt been recognized as the engine of economic growth and development as it contributes $45 \%$ of GDP in India 50\% of EDP in Poland and $45 \%$ in South Africa. It also serves a major variable for economic private sector, development and partnership. A various governments development agencies and experts as well as multilateral institution do appreciate this facts such that they positively respond to any recession and situations, which could permit their contributing to or creating opportunities for promoting this lot of standards (Ebringa, 2011).

One major drawback in Nigeria's quest for industrial development over the past years has been the absence of a strong, vibrant and mile sub-sector. A number of reasons have been adduced as to why the expectations from the SMEs have not been meet. They are: (1) devaluation of Naira (2) Political instability (3) Privatization 
According to Zaman (2011), the roles of SMEs in the economy include: (1) Theybooster an entrepreneurial spirit and put forward electricity in the economy. (2) SMEs are efficient in resource allocation as compare to that of large scale companies from social point of view.(3) They play significant contribution in the transition or agriculture led economics to industrial ones. (4) They contribution to improved living standards, substantial local central formation and high level of productivity. (5)They generate employment and alleviate poverty.

Onugu (ibid) asserted that the importance of SMEs to Nigeria Economic Development includes: (i) SMEs act as catalyst for technology development. (ii)They serve as major source of employment. (iii) They provide a training avenue for the creation of future entrepreneur in several area of economic activity.(iv) SMEs are a major source of domestic capital formation through their mobilization of savings and channelling of such in productive investment. (v)They aid the process of redistribution of incomes.(vi) SMEs provide intermediate/semi-processed goods for use by large-scale firms. (vii) SMEs engage in manufacturing serve as channels for import substitution and promotion of exports. (viii)

They provide sound development for improving the standard of living of the citizenry. (ix) SMEs provide a variety of choice to the customer. (x)They also constitute a critical source of specialization for most large organizations operating in the economy. (xi)SMEs facilitate structural transformation to the rural areas. (xii)SMEs help in improving rural incomes and general rural living conditions and by extension the country per capital income. (xiii) They also serve as a strategy for checking rural-urban migration and;(xiii)They in their limited ways help in reducing the development gap between these areas and the urban centres and in this way help sustain economic growth.

\section{Challenges of Small and Medium Enterprising Farmers in Nigeria}

Some challenges SMEs faced are: unfair competition, inadequate infrastructural facilities, inconsistent monetary fiscal and industrial policies limited access to markets, multiple taxation and levies, lack of modern technology for processing and preserving product, policy reversals, capacity limitations, data inadequacies, harsh operating environment, fragile ownership and capacity bases inadequate management skills (Alawode, 2005).

Onugu (ibid) identified the major problems confronting SMEs as: management problems, access to finance/capital, infrastructural problems, environment policy inconsistency and bureaucracy, 
environmental related problems, multi taxes and levied, access to modern technology, unfair competition, marketing related problems, non-availability of raw materials locally, lack of access to appropriate technology, high dependence on raw materials with the attendant high foreign exchange, weak demand for products arising from low and dwindling consumer purchasing power, absence of long-term finance of fund capital assets and equipment under project finance for SMEs, widespread corruption and harassment, weakness in organization marketing, information, lack of scientific and technological know-how, lack of strategic succession plan, lack of initiative and administrative framework to support and sustain SMEs development andlack of suitable training and leadership development

Most SMEs die within their first five years of existence. Another smaller percentage goes into extinction between the seventh and tenth year thus only about six percent of young companies survive, thrive and grow to maturity.

\section{Methodology}

The study was carried out in Ile-Ife Township of Osun State, Nigeria. Ile-Ife Township ofOsun State, Nigeria,Ile-Ife Townshipconsists of two local governments. The include Ife Central Local Area (situated at Ajenbandele Area of the city) and Ife East East Local Government situated at OkeOgbo.The major occupation is farming, trading, artisan and civil service. The major staple crops grown by the people are; cocoa, vegetables, cassava,yams, pam oil palm,maize,oranges etc. They also engage in lives livestock feeds production, aquaculture production and nonfarm activities.

The study group consists of Small and Medium Scale farmers in farm production,arable, farm input supply,farm distribution and marketing, and non-farm activities such as civil service, artisans trading.A multi stage random sampling technique was used in selecting the respondents for the study. Data collected mainly for primary source using structured questionnaires that was administered to the 120 randomly selected respondents. Both descriptive and inferential statistics were used in analyzing the data. Descriptive statistics such as mean, frequency tables and percentages were used in analysing in Table 1 while Table 2 was analysed using mean score derived from 4 point likert scale. 
Result and Discussion of Major Research Findings from Questionnaires

Table 1: Profileof Farmers in Ile-Ife Townshipof Osun State

\begin{tabular}{|c|c|c|c|c|}
\hline Variables & Description & Frequency $(\mathrm{N}=120)$ & Percen & se \\
\hline \multirow[t]{4}{*}{ Age (years) } & $21-30$ & 15 & 12.5 & 44 \\
\hline & $31-40$ & 21 & 17.5 & \\
\hline & $41-50$ & 50 & 41.7 & \\
\hline & $51-60$ & 34 & 28.3 & \\
\hline \multirow[t]{2}{*}{ Gender } & Male & 68 & 56.7 & \\
\hline & Female & 52 & 43.4 & \\
\hline \multirow[t]{3}{*}{ Marital Status } & Single & 34 & 28.3 & \\
\hline & Married & 77 & 64.2 & \\
\hline & Widowed & 9 & 7.5 & 6 \\
\hline \multirow[t]{3}{*}{ Household Size } & $1-5$ & 40 & $33 \cdot 3$ & \\
\hline & $6-10$ & 65 & 54.2 & \\
\hline & $10-15$ & 15 & 12.5 & \\
\hline \multirow[t]{4}{*}{ Educational Level } & Primary & 11 & 9.2 & \\
\hline & Secondary & 64 & 53.3 & \\
\hline & OND/NCE & 19 & 15.8 & \\
\hline & $\mathrm{HND} / \mathrm{BSC} / \mathrm{MSC}$ & 26 & 21.7 & \\
\hline \multirow[t]{4}{*}{ Business Experience } & $5-10$ & 13 & 10.8 & 16 \\
\hline & $11-16$ & 48 & 40.0 & \\
\hline & $17-22$ & 41 & 34.2 & \\
\hline & 23\& above & 18 & 15.0 & \\
\hline \multicolumn{5}{|l|}{ Annual Business } \\
\hline \multirow[t]{7}{*}{ Income } & \$50, 000 & 16 & 13.3 & 162,430 \\
\hline & $\$ 50,0001-\$ 100,000$ & 19 & 15.8 & \\
\hline & $\$ 100,001$ \$150,000 & 26 & 21.7 & \\
\hline & $\$ 150,001-\$ 200,000$ & 34 & 28.3 & \\
\hline & $\$ 200,001-\$ 250,000$ & 18 & 15.0 & \\
\hline & $\$ 300,001 \$ 350,000$ & 7 & 5.8 & \\
\hline & $\$ 400,001$ and Above & 2 & 1.7 & \\
\hline TotalAnnual Income & ફ50,0001-\$100,000 & 3 & 2.5 & 223,483 \\
\hline
\end{tabular}




\begin{tabular}{|l|l|l|l|}
\hline \$100,001-\$150,000 & 18 & 15 \\
& $\$ 150,001-\$ 200,000$ & 35 & 29.2 \\
$\$$ \$200,001-\$250,000 & 21 & 17.5 \\
& $\$ 250,001-\$ 300,000$ & 26 & 21.7 \\
\$300,001-\$350,000 & 6 & 5 \\
\$350,001-\$400,000 & 9 & 7.5 \\
\hline Others & & \\
\hline
\end{tabular}

\section{Source: Field Survey (April 2016)}

The result of analysis as presented in Table 1 showed that the business owners are within ages of 44 years. Gender analysis of the business owners show that more than half (56.7\%) of the respondents were males while $43.3 \%$ of them were females. It was observed that most (64.2\%) of the respondents were married with an average house hold size of six persons. This implies that the business owners who are engaged in the business enterprises in lle-Ife Townshiphave a relatively large household size. Also $53 \%$ of the respondents completed secondary school education which signified that the business owners have adequate education background that is relevant for business enterprise. Moreover, the result showed that the business owners earned an average annual business income of $\$ 162,430.00$ and the annual income of $\# 223,480.00$. The result implied their businesses are not moving due to the low level and dwindling consumer purchasing power.

Table 2: Distribution of the respondents according toactivities existing Ile-Ife Townshipof Osun State, Nigeria

\begin{tabular}{|l|l|l|}
\hline Categories of Entrepreneurship & Areas of Activities & $\begin{array}{l}\text { Frequency } \\
\%\end{array}$ \\
\hline Farm Input Supply & Livestock Feeds \\
& Seedlings \\
& Breeding Stocks & $24 \quad(20)$ \\
& Others & $48(40)$ \\
Farm Production & Arable Crop Production (e.g. cassava & $18(15)$ \\
& aize, yam etc) & $30(25)$ \\
& Livestock Production (e.g. poultry, & $21(17.5)$ \\
& piggery etc.) & \\
& Aquaculture (fisheries production) & $3(2.5)$ \\
\hline
\end{tabular}




\begin{tabular}{|l|l|l|}
\hline Farm Distribution/Marketing & Yam,Oranges \& Maize & $21(17.5)$ \\
& Palm oil, CocoaProducts & $72(60)$ \\
& and Cassava Products & \\
& Vegetables & \\
& Others & $3(2.5)$ \\
Non-Farm Activities & Civil Service & $21(17.5)$ \\
& Trading & $(48)(40)$ \\
& Artisan & $(39)(32.5)$ \\
\end{tabular}

\section{Source: Field Survey (April 2016)}

From the analysis of Table 2, it was established that under farm input category $40 \%$ are into seedling supply, $20 \%$ are into livestock feed supply, $15 \%$ are into breeding stock supply while $25 \%$ are into other activities.

In the farm production category, it was established that $80 \%$ of the farmers are into product such as cassava, and yam, $17.5 \%$ are into livestock production and $2.5 \%$ into fishery production.

The farm marketing and distribution activities of the farmers showed that $60 \%$ are into palm oil and cocoa products, $17.5 \%$ for oranges, yam and maize, $2.5 \%$ for vegetable and 17.5 for others.

From the non-farm activities of farmers the result showed that $27.5 \%$ are into artisan,32\% are into trading while $48 \%$ are into civil service. These results implied that farmers in lle-Ife Township engage into farm and non-farm small and medium scale farmers.

Table 3: Mean score distribution of the respondents based on the challenges of SME farmers in lleIfe Township of Osun State

\begin{tabular}{|l|l|l|}
\hline Challenges & Mean Score () & Decision \\
\hline Lack of strategic succession plan & 3.0 & Accepted \\
Poor managerial skills & 2.7 & Accepted \\
Poor road network & 3.5 & Accepted \\
Lack of access to capital & 3.8 & Accepted \\
High taxation & 2.5 & Accepted \\
Unfair competition & 2.8 & Accepted \\
\hline
\end{tabular}




\begin{tabular}{|l|l|l|}
\hline Weakness in organizational marketing \& & 2.6 & Accepted \\
Information & 2.9 & Accepted \\
Lack of suitable training & 3.3 & Accepted \\
Environment related problems & 3.6 & Accepted \\
Low and dwindling consumer purchasing & 2.0 & Rejected \\
power & 3.3 & Accepted \\
Lack of access to modern technology & & \\
Government policy inconsistency & & \\
\hline
\end{tabular}

Source: Field Survey (April 2016)

From the analysis of the result in Table 4, it was discovered that the challenges ofSmall and Medium Scale farmers in Ile-Ife Townshipof Osun State, Nigeria are: lack of access to capital, poor road network, lack of suitable training, high taxation, unfaircompetition, government policy inconsistency, low and dwindling purchasing power, weakness in organizational marketing and information etc.

This finding corroborated Onugu (ibid) that capital shortage, poor governance structure, poor basic infrastructure,lack of training are constraints militating against Small and Medium Scale Enterprising Farmers in Nigeria.

\section{Conclusion}

From the findings, it was established that the top key problem areas facing SME farmers generally in Nigeria descending order of intensity include managerial problems, access to finance/capital, infrastructure, government policy inconsistency and bureaucracy, environmental factors related problems inadequate sufficient finance, multiple taxes and levies access to modern technology, unfair competition marketing problems and the non-availability of raw materials locally.

There is however some opportunity windows which discerning Nigerian SME promoters can leverage on and taking advantage of to grow. The liberalization of trade through WTO Agreements has provided awareness through which SMEs could access international markets. Another opportunity is the African Growth Opportunity Act (ACOA) which favours exports from African countries to the United States of America. Current many SMEs in Nigeria are yet to tap into this opportunity (Mordi,2005).

\section{Recommendations}


In the light of the findings from the study the following recommendation are considered pertinent:

(1) The Federal Environment should establish more industrial development centers in every state of the federation.

(2) Government should tackle accelerate development and upgrade of rural urban road and rail network, water and air transport and other infrastructural facilities head on and review tariff in favour of small and medium entrepreneurs.

(3) Government should stimulate this provision of specific tax incentives for ventures specialists.

(4)They should reduce tax rate for SMEs and provide tax incentives to SME farmers.

(5) SMEDAN should through its business development provide more support in this area of capacity building and skill upgrades, identification of sources of funds with attractive interest rates.

(6) Environment should institutionalize the policy of all to ministries, agencies and department buying only made in Nigeria goods and services.

(7) SME farmers should honour payment obligations to banks, government or grant loan Agencies.

(8)SME farmers should provide needed statistics and information to relevant agencies whose contributions are vital to creating and sustaining an enabling environment.

(9)SMEDAN should assist SMEs in providing effective marketing and distribution channels of SMEs products to penetrate sub-regional global markets and; finally SME farmers should exploit ways of producing at low costs and selling at relatively low prices.

\section{References}

[1] Onugu, B. A (2005)Small and Medium Enterprises (SMEs) in Nigeria: problems and prospects.Unpublished PhD Thesis Submitted to St. Clement University Niue.

[2] Ajagu, A. (2005) SMEs do not enjoy any form of incentive. Business Day Newspaper, Business Day Media Ltd, Lagos.

[3] Fatai, A. (2011) "Small and Medium Scale in Nigeria:The problems and prospects. From www.theeje.com/journal/indexphp/economicjournal/artide/..8.

[4] Chowdhury, N. (2007) SMEs development in Bangladesh. Ministry of Industries report. 
[5] Mordi, F (2005) Manufacturer and CBN disagree on causes of SMEs stunted growth. Lagos: Millenium Harvest Ltd, Lagos.

[7] Gholami, R., Koh, E and Lim., J. (2010)“A Survey of the Post - Adoption of Internet” International Resource Management Journal. 23(1): 22- 35.

[8] Ahmed, K. (2009) “Performance evaluation of SMEs in Bangladesh”. International Journal ofBusiness Management, 4. 7.

[9] Ebiringa, T. (2011) “Entrepreneurship venturing and Nigeria manufacturing sector in focus"International Journal of Business Management and Economic Research. Vol. 12 (6): $376-381$. 